\title{
Indigenous Land Tenure Reforms in the Conservation of Common Property Resources in the High Forest Regions of South-Eastern Nigeria
}

\author{
Francis Bisong(Corresponding author) \\ Department of Geography and Regional Planning \\ University of Calabar, Calabar, Nigeria \\ Tel: 234-803-338-0315 E-mail: febisong@yahoo.com \\ Elizabeth Andrew-Essien \\ Department of Geography and Regional Planning \\ University of Calabar, Calabar, Nigeria \\ Tel: 234-802-390-3999Ｅ-mail: liessien@yahoo.ca
}

\begin{abstract}
Study examined the structure of local institutions and their response patterns in evolving mechanisms to deal with the problems of resource degradation in common lands and property resource use and decline, as well as the efficiency levels of resource use patterns under various land tenure regimes. Analysis of field data generated through Participatory Rural Appraisal (PRA) methods and questionnaire survey showed rapidly declining commons in terms of size and volume of harvestable forest products. A significant level of sub-optimality in the efficiency levels to which common property resources were utilized were also evident with no apparent distinction in resource use habits of communities governed by general and specific rights to land. This makes urgent the need for reforms in land acquisition and use practices for resource sustainability at the grassroots. Traditional institutions were found to be responsive and slowly evolving mechanisms to cop with resource degradation problems. Facilitating this process through policies designed to empower grassroots institutions and structures is an important development objective for consideration.
\end{abstract}

Keywords: Common Property Decline, Land Tenure, Resource Utilization, Rainforest Management, Nigeria

\section{Background}

The tropical moist forest area of Cross River State, Nigeria has the largest area of tropical high forest in the country, with approximately 8,506 square kilometers of mostly undisturbed virgin forestland, which accounts for about 2.4 percent of the total land surface of Nigeria (CRSFP 1994). A total of 29.5 percent $(2,150$ square kilometers) of tropical high forestlands of the Cross River State is under community ownership. The remaining 70.5 percent or 5,140 square kilometers of the tropical high forest land is designed as protected areas; comprising of the Cross River National Park which occupies 3,330 square kilometer of high forest, and the Forest Reserves occupying 1,810 square kilometers of forest land (CRSFP 1994).

The extensive form of agricultural land use and the porous and largely unregulated land tenure systems accounts for much of the on-going forest destruction in the region. Massive destruction of primary forest in the Cross River region which between 1971 and 1991 lost about 19\% of its tropical high forest (THF), and between 1991 and 2002 (Flasse, 2002) further recorded a loss of $22 \%$ of its THF, is clearly evident. It is estimated that at this rate of forest depletion, forest reserves will be completely cleared by the year 2014, while all other forest will be gone by 2035 A.D. (CRSFP, 1994; Bisong, 1994b; Flasse, 2002).

The forest legislation in Nigeria recognizes two main kinds of tenurial arrangements, (the state tenure and customary use rights), in accordance to the two broad categories of forestland. Resources held under communal ownership otherwise regarded as common property resources are subject to customary usage rights. The use rights are differentiated on the basis of the resource type in question such as cultivated fields, fallows, forests and specific trees of economic or socio-cultural importance. This study therefore is designed to examine the relationship between the prevailing land tenure systems and the pattern of resource use and degradation while assessing the emerging trends towards the evolution of indigenous land tenure reforms that incorporates regulatory mechanisms in the use of common property resources in the broader context of existing institutions and organizations, in order to explore how existing rural social structures could be empowered towards this end.

\subsection{Tenure Regimes, Evolution of Land Rights, Resource Degradation and Management}

Scholars have drawn attention to the dynamic nature of customary land tenure premised on changing socio-economic and technological conditions, and have correspondingly raised serious questions to the imageries of customary tenure long considered to be static and unchanging (Migot-Adhola \& Bruce, 1994). The assertion is that the most dominant organization of land rights in low-density population is "common property where members of a community have general cultivation rights rather than specific rights. They usually do have usufructuary rights to a plot when in cultivation, which reverts to the community when under fallow. On the 
contrary in high population density areas, cultivators are said to have "private property" rights, which entails a large array of rights, often implying a situation where the cultivator resumes the cultivation of a plot after the period of fallow (Pingali, 1990).

A growing body of literature nevertheless attests to the fact that resources managed under open-access, regimes are in modern times fast being decimated at an alarming rate (Repetto \& Holmes 1983, Jodha 1985, Pingali 1990, Jodha 1990, Arnold 1992, Bisong 1994a, Maler 1998, Lopez 1998). This is despite the growing consensus in the literature on the utility of strengthening the rural community towards common property resource management if long-term socio-economic and ecological stability in rural livelihood system are to be attained (Arnold, 1992; Bromley, 1993; Berkes and others, 1995; UNRISD, 1995; Brushett, 1998; Bisong, 1998). Many discussions concerning the degradation of the commons are premised on the thesis of the 'tragedy of the common' which asserts that increasing pressure on individual resource users hinder effective cooperation and group control (Hardin 1968 in Arnold 1992).

The arguments within this context focuses mostly on the perceived superiority of the private (individual) property rights as against communal ownership as tool for the rational management of natural resources (Karp, 1993 in Ogalla and Mugabe, 1996). Charkravarty-Kaul (1996) in Talwa and Ghate, (2004) argue that the ownership of a resource influences to a large extent the way that resource is used at present and managed for the future. When an individual owns a resource and can expect to own and profit from the resource and gets involved in the form of protective measures, restrained use and careful management. The absence of property rights arrangement would lead to over use and under-investment in the resource, due to free-rider problem. In the case of agro-forestry, it has been argued that the usual belief is that clear and secure land tenure arrangements must be in place as people will not be motivated to plant and maintain trees on land that they do not own or control (Uruh, 1995 in Talwar and Ghate (2004).

Despite the different policy perspectives advanced as an alternative to common property management regimes due to its inherent weaknesses, the bulk of the rural population in forested regions are still largely dependent on the vast array of social, economic, nutritional and ecological services drawn from the resources of the commons. The central role of the traditional collectives as the new focal point for resource management is fast gaining grounds. Reinvigorating the ability of the community to act collectively towards the mutual defined goals is the new agenda for long-term improvement of rural living conditions (Bisong 1998). Existing studies in the Cross River Region have focused on the over-riding problems of forest loss, conversion and conservation (Bisong, 1999, 2003). Little or no literature exists that explicitly captures the land tenure reforms that relate to the management and conservation of common property resources within unique African environments like Nigeria. This study sets out to full this gap.

\subsection{Land Tenure Typologies}

Community-based tenure and common property resources are two vital but highly related concepts needing clarification in order to provide an unambiguous conceptual underpinning to the study. Resource use and management regimes have been classified to provide distinction between open-access arrangements (understood to connote absence of rules or property rights) and common property regimes (with regulatory controls and rights). Theorists of property rights generally recognize four basic typologies of property ownership: individual (private), public (state controlled), common (group property) and open0access (absence of rights to exclude) arrangements (McKean, 1999; Lynch \& Alcorn, 1994). These may be differentiated into sub-types and further classified based on factors critical to their effective functioning, i.e. attributes of resources (the resource complex), attributes of appropriation (nature of resource use patterns), and attributes of institutions (management regimes) Stern, et al, 2002). For effective analysis of resource use and management regimes, distinction has to be made between resource systems, i.e. forest, river, fishery, regimes (rules and norms governing resource extraction and ownership) (Stern et al 2003, Agrawal, 2002). In the study region typical of low population density areas of the tropical moist forest of West Africa. Diverse models of tenurial arrangements are observed to characterize the acquisition of agricultural lands from primary forest as well as the gathering of products. These range from usufructuary cultivation rights that excludes, ownership of fallows, to outright privatization of fallows in land acquired from the common pool, to mixed variants of rights differentiated by resource type where land ownership is limited to cultivated lands with the farmer retaining ownership of land and crops, but excluding ownership of most forest trees of economic value on land. This is retained as community property. Forest and tree tenure bears some semblance to that of the land. The resources and trees of the open forest are 'commonly owned and may be freely exploited (largely consisting in products gathered) by all members of the community usually with limited or no restrictions as to use and access, although they may be subject to diverse community regulations as required. The communities in some fallows are communally or privately owned.

\section{The Setting}

The study area stretches across two main ecological zones of the Cross River State and spans from its Southern most to its Northern most part $\left(5^{\circ} 00^{\prime}\right.$ to $6^{\circ} 3^{\prime} \mathrm{N}$ and longitudes $8^{\circ} \mathrm{E}$ to $\left.9^{\circ} 15^{\prime} \mathrm{E}\right)$. They are namely the forest zone comprising The Tropical High Forest and disturbed forest, and the Montane/Grassland vegetation zone. Three 
major forestland use types are to be found within the zones. They are the National Park, the Forest Reserves and Community or Protected forests. Six communities located in the zones are detailed for study and have sizeable community owned forest estates. They reflect diverse ecological and socio-economic circumstances relative to the nature of vegetation, size of community owned forest, physical environmental conditions, location attributes by forest types, population and socio-economic characteristics. Table 1 show aspects of the above highlighted.

Six major forms of common property resources are identified in the study region. These include uncultivated closed canopy forest, Secondary forest and fallows, Pastures and rangelands, ponds, streams and rivers, economic, edible and medicinal forest trees on private land holdings, private croplands available for public use after crop harvest.

Forest resources have been historically managed in general open-access but assume more regulatory forms in the context of specific forest products. Farming, collection of non-timber forest product (NTFPs) and hunting are the predominant means of livelihood. Farming consists of rain fed extensive mode of cultivation characterized by rotational bush fallow and shifting cultivation regimes. Crop systems consist of mixed tree crops and cocoa, plantain and banana as dominant crops, mixed food crops of largely cassava, melon, maize and vegetables intercropped. While the tree crops are largely grown for commercial purposes, the food crops are largely consumed. Edible leaves, fruits, spices and fiber are the major NTFPs collected. These products are increasingly finding their way into markets for income generation.

\section{Methodology}

Field data for the study was carried out in three phases. This consisted of a two week reconnaissance survey as well as a detailed Participatory Rural Appraisal (PRA) study and a Field Questionnaire spanning through a twelve week period. The PRA survey centered, on "the local" traditional management regimes as the main unit of investigation and analysis such interview of village Elders and Chiefs, forma and informal Traditional Women Associations, Age-Grade and Forest Product Gatherers. It adopted Semi-Structured Interviews (SSI), Village Resource and Social Maps, Time lines and Trend Analysis ad main techniques of investigation. The SSI was adopted to assess the nature of tenure regime and analyze the structure of village level institutions and organizations. The village resource map was used to determine resource profile, nature of change and management plans, while trend analysis was adopted to determine change in resource stock. The household questionnaire survey focused on generating information on the land and forest use characteristics of the households such as mode of land acquisition, size of landholdings, size and frequency of forest clearings, ownership of idle forest plots, perception of tenure practices and household level response on local reform strategies. Household quantity and income data over time from the extraction of forest products were obtained, including suggestions on the community management of the declining resource stock.

The questionnaire was administered to one hundred and eighty five households across six villages. The choices of settlements were stratified across major ecozones/geographical divide. They were also selected to reflect differential population sizes relative to the size of community forest estates. The households were systematically sampled on the basis of orderly sequence of every nth house in each of the sampled villages. Samples were targeted to achieve between 20 to 40 percent coverage relative to the total number of households in each settlement.

\section{Results}

\subsection{Tenure and Resource use Typologies}

Six major forms of common-pool resources are already identified to exist in the region. The map-able entities of this resource complex are shown in Table 2 below. The largely undisturbed primary forest constitutes the largest chunk of common property 'resources in the study region. It occupies an average of approximately 81 percent of the total land area for all six sampled settlements in 1991. Cropland at 1991 estimate on the aggregate are about 12.46 percent of total land surface in the sampled region, and comes next to the primary forest as commonly accessible resources. The dense woodlot and fallows come next in significance to cropland as a common property resource. This from 1991 estimates on the aggregate occupies 6.36 in total land area. The nature of land trees and forest tenure regimes in the six sampled settlements are depicted in Table 3.

The table shows specific resource types of namely forests, fallows, farmlands and nature or uncultivated trees on farmlands. The tenure regimes governing access to specific resource types are shown for each of the settlements. In all communities, the forest although communally owned (common property) is managed as an open-access resource. Farmlands in all but one (Anape) community are privatized holdings in common lands. In Anape, access to farm land is governed by usufracturary rights i.e. the right to use but not owned. Fallow lands are privately owned in four of the communities. In Balegete, they are commonly owned but may be privatized if economic trees are planted. Fallows remain common-pool resources in Anape. Rights to uncultivated trees on farmland presents on interesting picture. While trees found during farmland establishment are the private property of farmers establishing claim over tracts of given lands in three communities, rights over non-cultivated/nature trees are retained by individuals cultivating the land in two communities (Balegete and 
Anape). This soon reverts to the common pool when the land is under fallow. In Butatong community, however, trees found on farmlands are commonly owned and cannot be privatized by the land cultivating individual.

Diverse models of tenurial arrangements may thus be observed to characterize the acquisition of agricultural lands from primary forest as well as the gathering of products. These range from usufructuary cultivation rights that excludes, ownership of fallows, to outright privatization of fallows in land acquired from the common pool, to mixed variants of rights differentiated by resource type where land ownership is limited to cultivated lands with the farmer retaining ownership of land and crops, but excluding ownership of most forest trees of economic value on land. This is retained as community property. The broad rights of access and ownership as earlier noted are however differentiated by tenure situations where fallows are managed as common property resources, with individual cultivators forfeiting rights of claim when land is under fallow, to outright ownership of fallows by individual cultivators. Forest and tree tenure bears some semblance to that of the land. The resources and trees of the open forest are commonly owned and may be freely exploited (largely consisting in products gathered) by all members of the community usually with limited or no restrictions as to use and access, although they may be subject to diverse community regulations as required. The community in some situation retains ownership of most or all economic trees of whether fallows are communally or privately owned. In this situation individuals and (community members have right to gather forest products during their peak seasons irrespective of where found-farmlands, fallows or open forest; except the product in question is planted by an individual and not occurring naturally. In other situations, forest products and economically useful forest trees found within cultivated lands (excluding fallows) are owned by individuals or cultivating families.

Within the general scope of traditional land tenure systems characterized by open-access resource use, communities have been characterized to transit or organize tenure arrangements from more diffused, collective and general cultivation rights to the more specific ad exclusive individual right. The six surveyed settlements may thus be characterized into three tenure typologies namely:

1) Typology A: Where tenure arrangements are governed by general rather than specific rights to farm plots and where rights to lands acquired from common forest are usufructuary and are not retained when plot is under fallow as it reverts back to community ownership. Anape, in the montane ecosystem is an example of settlement with typology tenure.

2) Typology B: Is a mixed variant of rights. In this case individuals have general rights of plots involving usufructuary use of land, which excludes the ownership of fallows. The rights over parcels may however be privatized in these communities when economic trees are cultivated ingrained in typology B tenure is a dual system of land rights. Balegate on the hillside is an example of this tenure arrangement.

3) Typology C: Is where tenure arrangement is governed by specific rather than general rights to farm plots, and where individuals retain, in perpetuity, their rights to land acquired from the community forest including when such lands are under fallow. The four communities of Butatong, Abomkpang, Iko-Ekperem/Owai and Etara/Eyeyen are governed by this holding arrangement.

Data dealing with selected attributes of forest resource use behaviour that portends resource degradation and those of resource use efficiency in agricultural land holdings were organized for the six sampled settlements along the lines of their tenure typologies relative to the degree of right an individual may have to specific land parcels. We may infer by causal inspection of data trends that frequency of clearing does not defer significantly across tenure typologies. With respect to the average size and number of idle farm plots degraded for claims taking, these land to be higher in communities with tenure typology $\mathrm{C}$. This may suggest a greater propensity for claims acquisition exist in communities with privatized land holding with open access forest use regimes, than those emphasizing common ownership with general land rights.

\subsection{INSTITUTIONAL STRUCTURES FOR COMMON PROPERTY RESOURCE MANAGEMENT}

An important objective of the study is to identify existing patterns of traditional institutions and structure of local organizations that are best suited to undertake sustainable land tenure reforms and redefine cultural practices that mitigate problems of natural resource degradation. There is hardly any community in the study region without well-defined institutions and organizational structures for managing natural resources. Although these have been little developed for regulating land tenure practices arising from agricultural processes, they nevertheless exist and are well defined for forest product harvesting, general sanitation and other aspects of natural resource management.

\subsection{Traditional Rules and Regulations in Natural Resource Management}

\subsection{Institutions for Regulating Non-Timber Forest Product (NTFP) Harvesting}

A number of local rules governing natural resource use and management exist ranging from the use of specific non-timber forest products (NTFP), use o communal systems, regulation of bush fires hunting etc.

Although the use of forest and its resources are largely governed by free and unrestricted access for all members of the community, specific forest products have stipulated norms regulating their harvesting.

The Bush Mango (Irvingia gabonensis) 
The Bush Mango (Irvingia gabonensis) for instance, a highly valued nut for income and food must not be cut down or climbed in the process of harvesting. Its fruit can only be harvested when it drops off naturally from the tree on maturing. This product has been on the decline from most of the community commons with respect to its volume of harvestable products. Sanctions are meted out when rules governing Bush Mango collection are breached. At Iko-Ekperem communities for instance, an offender is summoned and tried before the traditional village council. If fond guilty, he or she is required to pay as fine one goat, a bunch of plantain, 2 bottles of English hot, a cartoon of beer, a bottle of palm oil, 4 bottles of locally brewed gin, 1 cup of pepper, 5 maggi cubes and 25 cents worth of salt. The same sets of penalties are meted out in other commodities with slight variations.

\section{Salad (Gnetum Africana)}

Gnetum Africana commonly referred to as Salad is a climber most valued as food, income and medicine provider. This must never be uprooted during harvesting as it severely impairs its regeneration capacity. Offenders are normally summoned and tried in each community before their respective traditional village councils. Usually a live goat, a cartoon of beer, and a bottle of English hot are paid as fine on proof of guilt. In some communities such as Etara/Eyeyen, the fine in addition includes thigh (lap) of Red Deer (Tragelaphus scriptus). Other trees and shrub species of economic; medicinal and cultural value that must not be cut down during product harvesting, set on fire during farm making or destroyed under whatever circumstances in the course of forest clearing for agriculture include the Native Pear (Dacryodis edulis), Native kola (Kola accuminata), Bitter kola (Garcinia kola), Ricinodendron heudelottii and Sarcocepholus diderrichii. Stiff fines are normally imposed on offenders, while cultic groups as the Ekpe society and the traditional village councils assist in enforcing compliance. In Balegate on the southern slopes of the Obudu Plateau, those who cut down the species Ricinodendron heudelottii locally referred to as Okosoko are usually fined a goat and seven kola nuts. The alternative punishment from failure to pay is to hang oneself.

\subsubsection{The Structure of Community Organization in Natural Resource Management}

Both formal and informal village level organizations exists that serve to administer, monitor and enforce compliance to collectively agreed norms and behaviours guide the use and management of common property resources. This in a nutshell includes the traditional community government, the age grade, women organizations and religious, cultural and cultic groups such as the Mgbe or Ekpe (Leopard society). More formal organizations at the grassroots created through the joint initiatives of governmental agencies and the communities exist. A few known ones are the Forest Management Committees (FMCs) and village Integrated Rural Development Committee (VIRD). A number of these organizations largely constitute the basic nucleus for resource management at the grassroots. The degree to which they have direct interface with issues of natural resource use and control are highlighted.

\subsubsection{Traditional Community Government (Leadership Patterns and Lines of Authority)}

The traditional village government is at the apex of community leadership responsible for maintaining law and order and settling disputes arising from resource as well as fashioning the broad policies guiding land tenure. Different models of local leadership patterns, traditional lines of authority and patterns of decision taking are evident in the sampled villages. Their essential characteristics consist of three main typologies.

Typology 1: A diversified or simple hierarchy of leadership system rooted in kinship with representation from the micro to the macro family units.

Typology 2: Separation of power with the central village leadership arbitrating over civil matters while the more traditional system of authority based on age arbitrating over spiritual, mystical or non-civil matters. In some situations the Mgbe/Ekpe (leopard society) is considered to be at par with the central village government functioning as the final court of arbitration and the ultimate vehicle of enforcing compliance to sanctions. In some other situations, the umbrella women association exercise parallel functions with the male dominated central village council but largely over women affairs.

Typology 3: A largely top-down approach to decision taking with an opportunity for bottom-up participation in the decision making process.

The diverse shades and blends in one or more of these characteristics representing the different models are shown as Typologies 1 to 3 in figures $2 \mathrm{~A}$ to $\mathrm{C}$. At the apex of the arrangements are the village council composed of the respective village heads and elders representing the main families in the community. Their function includes the general administration of the community, dispute resolutions and peace settlements. They allocate lands for building, adjust boundaries and may delegate authority, as they deem appropriate. They play supervisory/advisory roles to all other village level units and organs set up for forest and natural resource management such as the local FMC and Women Organizations. They also act as vehicles for enforcing community discipline as well as enforcing sanctions and compliance to forest management rules. Next to the apex are the village councils and in some situations the youth council. They execute decisions taken at the apex council and may assist in maintaining peace and order such as mobilizing for village tasks and theft control. 


\subsection{Traditional Women Associations}

Although a number of women associations may be found with functions ranging from the religious cultural, social and economic, such as performing spiritual efficacies and assisting members in group labour during farm work, there had always existed a central or Umbrella Women Association. Their functions largely involve the settlement of disputes among women. They play mediator roles in the event of a serious conflict among males or families in the community. Their more specific functions in the area of sanitation and general resource management is in all communities situated include organizing community labor to clean up the village streams, clearing paths to drinking water sources and keeping the general surrounding clean. They also play crucial roles in regulating forest resource exploitation through a fee collection system imposed on outside gatherers. When the prices of forest product falls, for instance through over harvesting, they may give an order for the cessation of harvest in order to stabilize prices.

\subsubsection{The Mgbe, Ekpe or Leopard Society}

The Mgbe is a cultural organization that exists in most community's studies. They function as a secret society. The Mgbe constitute the ultimate court of arbitration and discipline on civil and financial matters within the community and enforce compliance on defiant behaviours. In many communities, offences bordering on improper harvesting of economic trees like the Native Pear, Raffia Palm, Bush Mango, Salad, and water-poisoning crimes are usually tried and disposed of by the village government. When unresolved, they are usually transferred to the Mgbe where stiffer penalties may be meted out.

\subsection{Forest Management Committees (FMCS) and Village Integrated Rural Development Committees (VIRDCS)}

The FMCs is recently evolved mechanism of making communities participate in forest management decisions initiated by government and external donor organizations. They were created by the traditional village government in all communities were they exist through the facilitation provided by the UK-DFID funded Cross River State

Forestry Commission. Presently the FMCs concentrates most of their efforts in regulating and monitoring timber exploitation by local dealers and firms operating in their community territories. The management of NTFPs are presently secondary in their activity schedule. The FMCs is not autonomous organizations but is responsible to the communities and traditional village governments that set them up. Presently they exert reasonable control in the communities studied on access to and utilization o forest resources. VIRDCs were created in 1994 through the facilitation provided by the Cross River National Park (CRNP). This is to enable local presence and feedback to the Community Development Programmes initiated by the CRNP. They focus on a range of activities such as agriculture, health, civil works, trade and industry, women in development, rehabilitation of hunters and environmental education.

The above institutions and organizations so far reviewed show strong social assets such as in-built cohesion and instruments of enforcing sanctions to commonly agreed norms that may be relied upon to foster efforts at collaborative common property management. Although community institutions have been systematically eroded through the influence of modernization forces, a number of these have proved resilient and show signs of institutional adaptation to contain resource management problems at the grassroots. It is hoped that this may be relied upon to evolve rational land use and tenure design for local resource management.

\section{Institutional Response and Adaptation Patterns in Common Property Resource Management}

Exploring the pattern and capacity of traditional institutions to adapt to benign forms of resource use and behaviour through redefining cultural practices to cope with changing environmental conditions is integral to the study objective. This is in the backdrop of views gaining currency in the literature on the failure of collective action for common property management under open-access regimes. These views seem to suggest that resource scarcity do not include institutions to improve natural resource management (Lopez 1998b). Evidence from the study do suggest however, that human systems do process ecological signals and respond accordingly and that institutional structures respond to resource degradation and may evolve management plans that redefine tenure rules to resource acquisition. Adaptation patterns and perceptions of traditional collectives are ere presented for the sampled communities. The households and local management regimes constitute the main units of analysis.

\subsection{Institutional Adaptations to Resource Management Problems by Local Management Regimes}

The declining stock of harvestable volume of forest products from the common pool (Table 5), and other associated forms and consequences of environmental degradation such as declining soil fertility, biodiversity decline and loss of economic opportunities are evoking a response from the traditional institutions, which are evolving mechanisms to control them. Table 5 data shows that the major forest products harvested in the region are on the decline in terms of the quantity harvested on a monthly basis in the gathering season. Values at earlier periods between 1980 and 1985 were generally low, as the products were not significantly integrated into the market economy. These began to nose dive after 1990 due to their declining stock in the open forest. The traditional women organizations, the sacred religious groups, some formal local 'white collar' organizations working through a functional traditional government are the most successful so far in evolving mechanisms for 
common property resource management. The experience of a typical traditional women group and that of a local level Forest Management Committee (FMC) is highlighted.

\section{Conclusion}

Well-defined institutions stipulating norms that guide resource use and management are intact in all communities investigated together with a system of sanctions enforceable through the structure of local organizations. Institutions and organizations are slowly but steadfastly evolving forms of source management through a redefinition of cultural practices that governs resource use. This change is largely conditioned by growing resource scarcity and environmental degradation. The rural households and the various local community management organs appear set and supportive of programs to evolve better habits of land use and tenure that is compatible with the goals of resource sustainability. They are also willing to proffer ideas to make this work based on the rich repository of indigenous knowledge and experience. Urgent reforms in rural land acquisition pattern are required. This is the background of the present largely unregulated land tenure that precipitates a preponderance of resource. The well defined structure of local institutions and organizations that show clear patterns of evolving early mechanisms to regulate resource use in response to scarcity conditions needs to be sensitized, empowered and made the main focus of land reform programs for rural resource sustainability.

\section{Acknowledgement}

The authors gratefully acknowledge the Robert S. McNamara Fellowship Program of the World Bank, Washington, D.C. for the financial support and fellowship to undertake this study.

\section{References}

Agrawal, A. (2002). Common Resources and Institutional Sustainability in Ostrom, E. et al (ed) The Drama of the Common. National Academy Press, Washington, D. C.

Arnold, J. E. M. (1992). Production of Forest Product in Agricultural and Common Land Systems: Economic and Policy Issues. In Sharma, Narendra E.Eds, Managing the World's Forest. lowa: Kendal/Hunt Publishing Company.

Berker, D. et al. (1999). indigenous Forest Management in the Bolivian Amazon: Lessons from the Yuracare People in Gibson, C. C. Mckean, M. A. \& Ostrom, E. eds. People and Forests: Communities, Institutions and Governance. Cambridge, MA: MIT Press.

Berkes, C. et al. (1995). Sustainability of a Mountain Watershed Ecosystem in the Himachal Pradesh Himalayan: Background and Overview. Canada: University of Manitoba, Natural Resources Institute.

Bisong, F. E. (1994a). Farming Systems, Human Ecology and Biodiversity Conservation in the Cross River Rainforest of Nigeria. Ph.D. Thesis, University of Port Harcourt, Nigeria, Department of Geography.

Bisong, F. E. (1994b). Farming System, Human Ecology and Natural Resource Conservation in Cross River State Rainforest. Report to the Cross River State Forest Project (ODA Assisted), Calabar, Nigeria.

Bisong, F. E. (1998). Three Model Community Participation in Forest Management in Cross River State. Technical Report to the Cross River State Forestry Commission, Calabar.

Bisong, F. E. (1999). Deforestation and the Erosion of Biodiversity in the Cross River State Rainforest, South Eastern Nigeria. In Global Journal of Pure and Applied Science, Vol. 5, No. 1 (1999), pp. 241-250. Department of Geography, University of Calabar.

Bisong, F. E. (2001). Community Institutions \& Resource Management Resilience and Adaptation of Traditional Mechanisms for Sustainability. In South-South Journal of Culture and Development. Special Edition Vol. 3, No. 2, p. 92-131.

Bisong, F. E. et al. (2003). Agricultural Land Use Modeling and Deforestation: An Analysis of Proximate Drivers in South-eastern Nigeria. Ghana Educational Media and Technology Association Journal (GEMTAT) Vol. 5, 2003 pp. 47-64.

Bromley, D. et al. (1992). Natural Resource Degradation at the Local Level. Unpublished paper R 1-22.

Bromley, D. (1993). Common Property as Metaphor: Systems of Knowledge, Resources and the Decline of Individualism. The Common Property Resource Digest No. 27: 1-9.

Brushett, L. (1998). The Art of Getting Things Done the Role of Social Capacity in Sustainable Rural Community Development. Lynda Brushett Nide Marketing Unpublished Paper R 1-3.

CRSFE (1994). A Strategy for Sustainable Development, Conservation and Management of the Forest of Cross River State. Forestry Development Department, Cross River State, and Cross River State Forestry Project (ODA Assisted).

Flasse, S. et al. (2002). Rapid Appraisal of Forest Resources from remotely sensed data Cross River State, Nigeria. Final Report CRSFP, Calabar.

Jodha, N. S. (1985). Population Growth and the Decline of Common Property Resource in Rajasthan, India. In Population and Development Reviews Volume No. 2. R 247-264. 
Jodha, N. S. (1990). Depletion of Common Property Resources in India: Micro-Level Evidence. In McNicol, Geoffrey, \& Cain Mead. Rural Development and Population: Institute and Policy Ede. Population and Development Review. A Supplement to Volume 15. The Population Council New York.

Lopez, et al. (1998). The Tragedy of the Commons and Implications for Trade Policies. The World Bank Economic Review Volume 12 No. 1.

Lynch, et al. (1994). Tenurial rights and community-Based conservation. In Natural Connections: Perspectives in Community-Based Conservation. Eds Western and Wright, Island Press, ISBN 1-55963-346-8, pg. 373-391.

Mabogunje, A. L. (1992). Integrated Rural Development. In Social Transformation Reliance: Proceeding of a National Conference ER, Foundation Publishes, Ibadan.

McKean, M. A. (1999). Common Property: What is it, What is it Good for, and What makes it work? In Gibson, McKean \& Ostrom (eds) People and Forests: Communities, Institutions, and Governance. Workshop in Political Theory and Policy Analysis. Cambridge, M.A: MIT Press. Forthcoming.

Maler, K -Goran. (1998). Environment, Poverty and Economic Growth. Annual World Bank Conference on Development Economics. Washington, D.C. The World Bank.

Migot-Hdholla, S.E. \& Bruce, J. W. (1994). Introduction: Are Indigenous African Tenure Systems Insecure. In Bruce, J. W. \& Migot-Adholla S.E., Searching For Land Tenure Security in Africa . Washington D.C. The World Bank.

Pingali, L. (1990). Institutional And Environmental Constrain To Agricultural Intensification. In MCN: Geoffrey And Cain Mead Eds. Rural Development And Population. Institutions And Policy. New York: Oxford University Press.

Repetto R \& Holmes T. (1983). The Role Of Population In Resource Depletion. In Population And Development Review Volume 9 No.4.

Stern, P. C, Dietz T, Dolsak N, Ostrom E \& Stomich, S. Knowledge and Questions after 15 Years of Research in Ostrom, E, et al (eds) The Drama of the Commons National Academy Press, Washington, D. C.

Talwar, D. M and Ghate, R. (2004). Community-initiated forest management without land tenure. How feeble, How strong? A study of three villages from Central India. Kathmandu, Nepal, South Asian Network for development and environmental economics.

UNRISD. (1995). Environmental Degradation and Social Integration UNRISD BRIEFING Paper Series 3.

Table 1. Sampled Settlements and some attributes of the Study Area

\begin{tabular}{|l|l|l|l|l|l|}
\hline S/n & Village & $\begin{array}{l}\text { Population } \\
1996\end{array}$ & $\begin{array}{l}\text { Size of community } \\
\text { forest estate }(\mathrm{Km})^{2}\end{array}$ & $\begin{array}{l}\text { Vegetation } \\
\text { status }\end{array}$ & $\begin{array}{l}\text { Locational attributes } \\
\text { by forest land types }\end{array}$ \\
\hline 1 & Balegete & 1090 & 12.50 & $\begin{array}{l}\text { Forest/ } \\
\text { Montane/ } \\
\text { Grassland }\end{array}$ & $\begin{array}{l}\text { National Park/ } \\
\text { Community Forest }\end{array}$ \\
\hline 2 & Anape & 271 & 18.00 & $\begin{array}{l}\text { Montane/ } \\
\text { Grassland }\end{array}$ & $\begin{array}{l}\text { National Park/ } \\
\text { Community Forest }\end{array}$ \\
\hline 3 & Butatong & 1376 & 37.06 & Rainforest & $\begin{array}{l}\text { Community Forest/ } \\
\text { National Park/Forest } \\
\text { Reserve Forest/ }\end{array}$ \\
\hline 5 & Abomkpang & 751 & 48.25 & $\begin{array}{l}\text { Community Forest } \\
\text { National Park/Forest } \\
\text { Reserve }\end{array}$ \\
\hline 6 & Etara/Ekuri-Eyenyen & 1213 & 34.08 & $\begin{array}{l}\text { Rommunity Forest/ } \\
\text { National Park/Forest } \\
\text { Reserve }\end{array}$ \\
\hline Iko-Ekperem/Owai & 3730 & 135.50 & Rainforest & $\begin{array}{l}\text { Community Forest/ } \\
\text { National Park/Forest } \\
\text { Reserve }\end{array}$ \\
\hline
\end{tabular}

Source: *National Population Commission, Census 1991, Cross River State **Cross River State Vegetation, 1996 
Table 2. Profile of Forest and Land Resources

\begin{tabular}{|c|c|c|c|c|c|c|c|}
\hline $\begin{array}{l}\text { Forest \& } \\
\text { Land } \\
\text { Resource }\end{array}$ & $\begin{array}{l}\text { All } \\
\text { Region }\end{array}$ & Balegete & Anape & Butatong & Abomlpang & $\begin{array}{l}\text { Iko-Ekperem/ } \\
\text { Owai }\end{array}$ & $\begin{array}{l}\text { Etara/ Ekuri- } \\
\text { Eyeyen }\end{array}$ \\
\hline $\begin{array}{l}\text { Total land } \\
\text { area }\left(\mathrm{km}^{2}\right)\end{array}$ & 364.06 & 22.75 & 32.50 & 50.81 & 53.50 & 168.25 & 36.25 \\
\hline $\begin{array}{l}\text { Percentage of } \\
\text { land area } \\
\text { covered }\end{array}$ & 92.18 & 73.36 & 99.05 & 90.16 & 98.99 & 91.05 & 95.26 \\
\hline $\begin{array}{l}\text { Community } \\
\text { forest estate } \\
1991\left(\mathrm{~km}^{2}\right)\end{array}$ & 294.70 & 12.50 & 27.36 & 37.06 & 48.25 & 135.50 & 34.03 \\
\hline $\begin{array}{l}\text { Percentage of } \\
\text { cropped area } \\
\text { to land area }\end{array}$ & 4.50 & 14.29 & 0.31 & 3.44 & 0.36 & 5.19 & 3.01 \\
\hline $\begin{array}{l}\text { Cropped area } \\
1991\left(\mathrm{~km}^{2}\right)\end{array}$ & 46.03 & 5.65 & 2.85 & 9.62 & 3.15 & 22.92 & 1.84 \\
\hline $\begin{array}{l}\text { Percentage of } \\
\text { cropped area } \\
\text { to total land } \\
\text { area }\end{array}$ & 12.64 & 24.84 & 8.77 & 18.93 & 5.89 & 13.62 & 5.07 \\
\hline $\begin{array}{l}\text { Percentage of } \\
\text { land area } \\
\text { covered }\end{array}$ & 3.72 & 12.35 & 0.65 & 6.40 & 0.65 & 3.76 & 1.71 \\
\hline $\begin{array}{l}\text { Fallow/ } \\
\text { Dense wood } \\
\text { and area } \\
1991\left(\mathrm{~km}^{2}\right)\end{array}$ & 23.14 & 4.60 & 1.67 & 4.13 & 2.10 & 9.85 & 0.81 \\
\hline $\begin{array}{l}\text { Percentage of } \\
\text { land area } \\
\text { covered }\end{array}$ & 6.36 & 20.22 & 5.14 & 8.13 & 3.93 & 5.84 & 2.23 \\
\hline $\begin{array}{l}\text { Population } \\
\mathrm{km}^{2} 1963\end{array}$ & 8.47 & 21.41 & 3.63 & 10.47 & 3.93 & 8.49 & 8.56 \\
\hline $\begin{array}{l}\text { Population } \\
\mathrm{km}^{2} 1991\end{array}$ & 20.14 & 41.54 & 7.23 & 23.95 & 12.17 & 19.21 & 28.99 \\
\hline $\begin{array}{l}\text { Population } \\
\mathrm{km}^{2} 1996\end{array}$ & 23.16 & 47.91 & 8.34 & 27.08 & 14.04 & 22.17 & 33.46 \\
\hline
\end{tabular}

Source: Author's compilation from aerial photographs, 1972 - 1991 (for Land Use Date) Size of Forest Estate Delineated from Cross River State, vegetation.

1:250,000. Crop and fallow area data for Anape are estimated from field survey

Aerial photo data could not be delineated. No attempt has been made to disaggregate grassland from forest in Anape a Montane ecosystem area. 
Table 3. Land and Forest Tenure Regimes in Sampled Settlements

\begin{tabular}{|c|c|c|c|c|c|c|}
\hline Village & $\begin{array}{l}\text { General } \\
\text { Nature of } \\
\text { Access to } \\
\text { Resource }\end{array}$ & Forest & Farm land & Fallow land & $\begin{array}{l}\text { Trees on farm } \\
\text { lands }\end{array}$ & Ecozone \\
\hline Balegete & $\begin{array}{l}\text { Open access } \\
\text { regime }\end{array}$ & $\begin{array}{l}\text { Common } \\
\text { property } \\
\text { open } \\
\text { access }\end{array}$ & $\begin{array}{l}\text { Private } \\
\text { ownership in } \\
\text { common lands }\end{array}$ & $\begin{array}{l}\text { Commonly } \\
\text { owned but } \\
\text { privatized } \\
\text { where } \\
\text { economic trees } \\
\text { are planted }\end{array}$ & $\begin{array}{ll}\begin{array}{l}\text { Owned } \\
\text { cultivation }\end{array} & \text { by } \\
\text { individual. } & \\
\text { Reverts } & \text { to } \\
\text { community } & \text { in } \\
\text { fallow } & \text { if } \\
\text { unclaimed by } \\
\text { economic trees }\end{array}$ & $\begin{array}{l}\text { Hillside/ } \\
\text { Montane } \\
\text { cultivation }\end{array}$ \\
\hline Anape & Open access & $\begin{array}{l}\text { Common } \\
\text { property } \\
\text { open } \\
\text { access }\end{array}$ & $\begin{array}{l}\text { Usufructuary } \\
\text { (right to use } \\
\text { not owned) }\end{array}$ & $\begin{array}{l}\text { Common } \\
\text { ownership }\end{array}$ & $\begin{array}{lr}\text { Owned } & \text { by } \\
\text { individual } & \text { in } \\
\text { cultivation } & \\
\text { Revert } & \text { to } \\
\text { community } & \text { in } \\
\text { fallow } & \end{array}$ & $\begin{array}{l}\text { Montane } \\
\text { grassland }\end{array}$ \\
\hline Butatong & Open access & $\begin{array}{l}\text { Common } \\
\text { property } \\
\text { open } \\
\text { access }\end{array}$ & $\begin{array}{l}\text { Private } \\
\text { ownership in } \\
\text { common lands }\end{array}$ & $\begin{array}{l}\text { Private } \\
\text { ownership }\end{array}$ & $\begin{array}{l}\text { Common } \\
\text { property }\end{array}$ & $\begin{array}{l}\text { Lowland } \\
\text { rainforest }\end{array}$ \\
\hline Abomkpang & Open access & $\begin{array}{l}\text { Common } \\
\text { property } \\
\text { open } \\
\text { access }\end{array}$ & $\begin{array}{l}\text { Private } \\
\text { ownership in } \\
\text { common lands }\end{array}$ & $\begin{array}{l}\text { Private } \\
\text { ownership }\end{array}$ & $\begin{array}{l}\text { Privatized when } \\
\text { land is under } \\
\text { cultivation }\end{array}$ & $\begin{array}{l}\text { Lowland } \\
\text { rainforest }\end{array}$ \\
\hline Iko-Ekperem & Open access & $\begin{array}{l}\text { Common } \\
\text { property } \\
\text { open } \\
\text { access }\end{array}$ & $\begin{array}{l}\text { Private } \\
\text { ownership in } \\
\text { common lands }\end{array}$ & $\begin{array}{l}\text { Private } \\
\text { ownership }\end{array}$ & $\begin{array}{l}\text { Privatized when } \\
\text { land is under } \\
\text { cultivation }\end{array}$ & $\begin{array}{l}\text { Lowland } \\
\text { rainforest }\end{array}$ \\
\hline $\begin{array}{l}\text { Etara/Ekuri } \\
\text { Eyeyen }\end{array}$ & Open access & $\begin{array}{l}\text { Common } \\
\text { property } \\
\text { open } \\
\text { access }\end{array}$ & $\begin{array}{l}\text { Private } \\
\text { ownership in } \\
\text { common lands }\end{array}$ & $\begin{array}{l}\text { Private } \\
\text { ownership }\end{array}$ & $\begin{array}{l}\text { Privatized when } \\
\text { land is under } \\
\text { cultivation }\end{array}$ & $\begin{array}{l}\text { Lowland } \\
\text { rainforest }\end{array}$ \\
\hline
\end{tabular}

Source: Author's Survey

Table 4. Forest use Efficiency and Tenure Typologies

\begin{tabular}{|l|c|c|c|c|c|c|}
\hline \multirow{2}{*}{ Forest Use Characteristics } & \multicolumn{3}{|c|}{ Tenure Typology } & Mean & $\begin{array}{c}\text { Stat } \\
\text { Deviation }\end{array}$ & $\begin{array}{c}\text { Coefficient of } \\
\text { Variation }\end{array}$ \\
\cline { 2 - 6 } & $\mathbf{A}$ & $\mathbf{B}$ & $\mathbf{C}$ & & 9.0 & 10.00 \\
\hline $\begin{array}{l}\text { Percentage household of clearing of virgin } \\
\text { forest }\end{array}$ & 100 & 89.29 & 83.02 & 89.80 & & 24.43 \\
\hline $\begin{array}{l}\text { Frequency index of virgin forest clearance } \\
(\%)\end{array}$ & 87.10 & 59.50 & 79.03 & 93.94 & 18.16 & 37.20 \\
\hline $\begin{array}{l}\text { Ownership of idle forest (\%) Average size } \\
\text { of idle }\end{array}$ & 63.64 & 53.57 & 78.81 & 65.67 & 23.31 & 49.1 \\
\hline Forest Plots (ha) & 154.50 & 164.28 & 221.8 & 180.21 & 83.26 & 37.4 \\
\hline Number of idle forest plots & 51 & 46 & 213 & 103.33 & 38.58 & \\
\hline $\begin{array}{l}\text { Size of the forest plots as ratio of sampled } \\
\text { population }\end{array}$ & $8: 1$ & $4: 1$ & $6: 1$ & $6: 1$ & & \\
\hline
\end{tabular}

\footnotetext{
Typology A: General Land Rights (Tend Towards Common Ownership)

Typology B: $\quad$ Mixed Variants (Usufructury/privatized were trees are planted)

Typology 3: $\quad$ Specific Land Rights (Privatized holdings in common lands).
} 


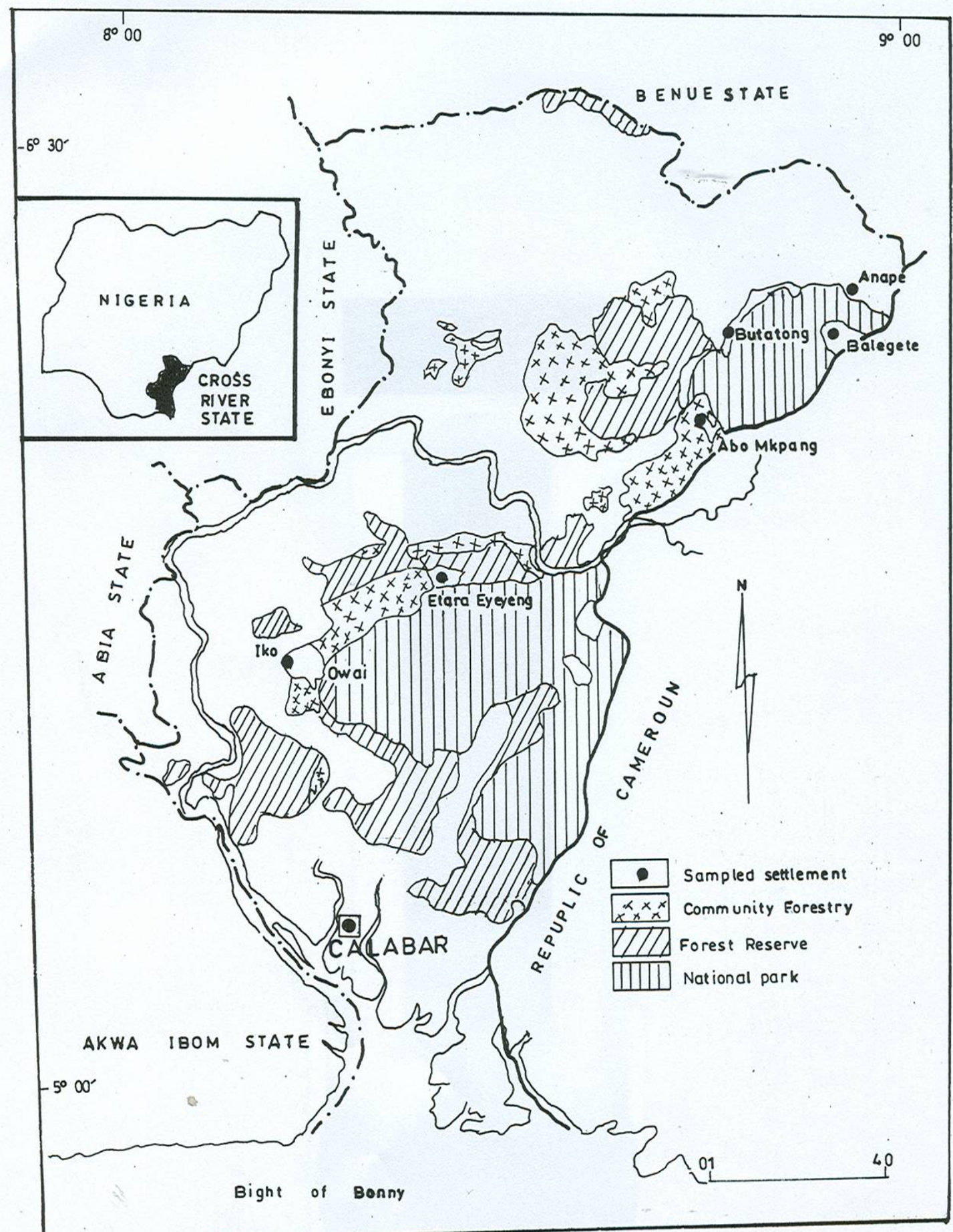

Fig.1: Study area showing sampled settlement and Forest Estates 


\section{TYPOLOGIES}

Typology 1: A Diversified Model of Hierarchical Leadership with Parallel form of Government by Traditional Elders.

Elders of the Tribe \& Custodians of Ekumbuk (juju)

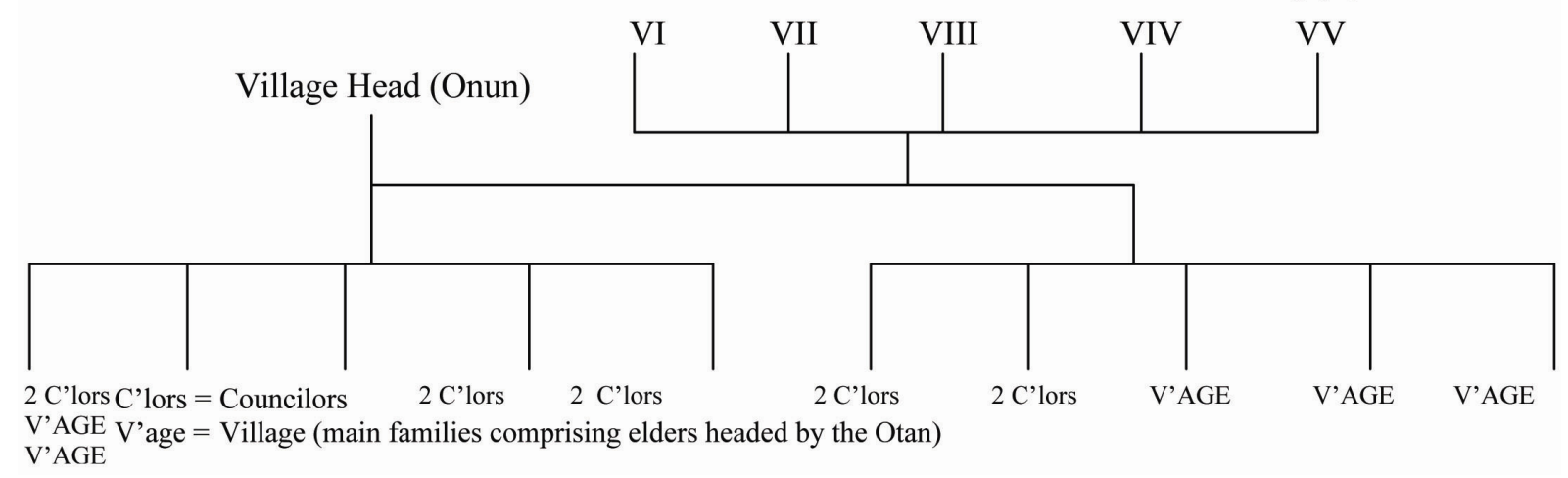

Figure 2A. Balegate

Typology 2: $\quad$ Leadership System \& Pattern of Decision taking, with Balance of power Represented in the Oldest Living person or Group of Elders.

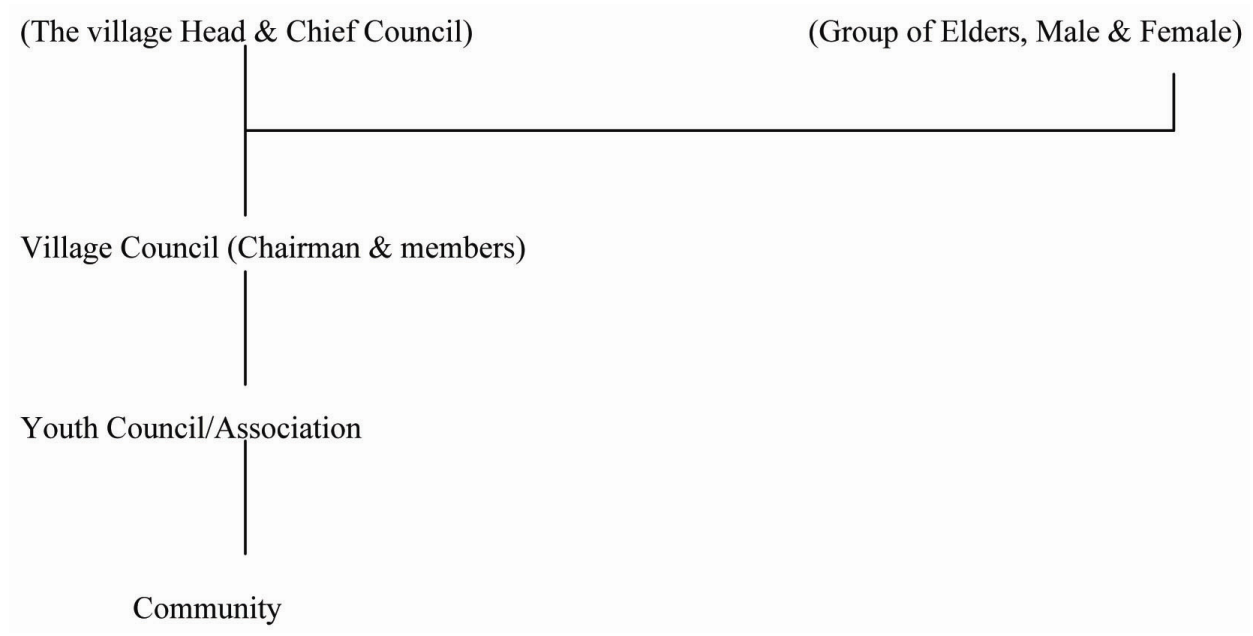

Figure 2B. Abo Mkpang \& Etara/Ekuri-Eyeyen

Typology 3: Hierarchical Leadership with Balance of Judicial Power by Ekpe/Mgbe Society and Women Council Parallel to Central Village Council.
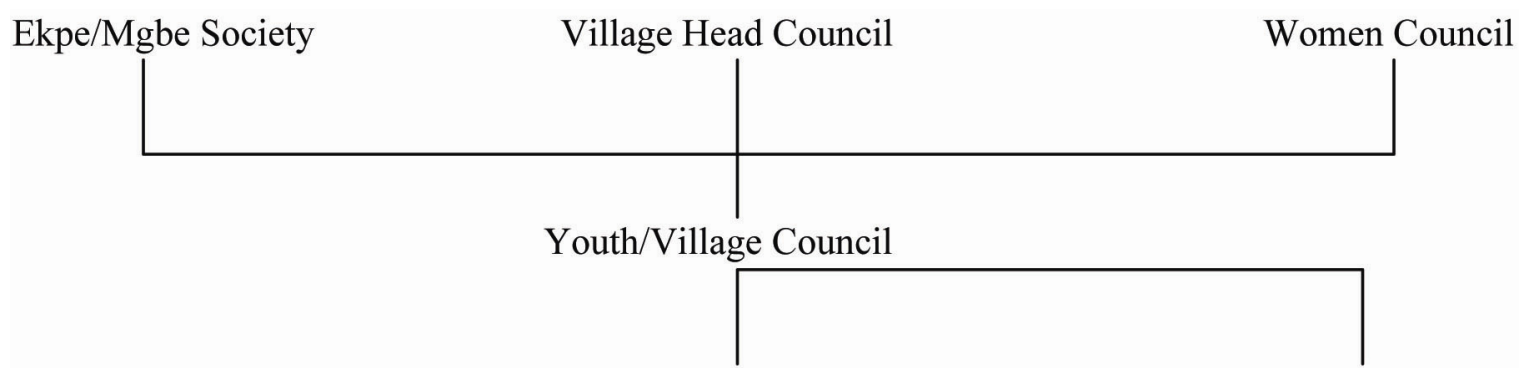

Village/Community

FMC \& Others

Figure 2C. Iko-Ekperem/Owai 